\title{
Proteolytic enzymes from Bromelia antiacantha as tools for controlled tissue hydrolysis in entomology
}

\author{
Laura Macció ${ }^{1,3}$, Diego Vallés ${ }^{1,3}$ and Ana Maria Cantera ${ }^{1,2,4^{*}}$
}

\begin{abstract}
A crude extract with high proteolytic activity $(78.1 \mathrm{EU} / \mathrm{mL})$, prepared from ripe fruit of Bromelia antiacantha was used to hydrolyze and remove soft tissues from the epigyne of Apopyllus iheringi. This enzymatic extract presented four actives isoforms which have a broad substrate specificity action. Enzyme action on samples was optimized after evaluation under different conditions of $\mathrm{pH}$, enzyme-substrate ratio and time (parameters selected based on previous studies) of treatment ( $\mathrm{pH} 4.0,6.0$ and 8.0 at $42^{\circ} \mathrm{C}$ with different amount of enzyme). Scanning electron microscopy was used to evaluate conditions resulting in complete digestion of epigyne soft tissues. Optimal conditions for soft tissue removal were 15.6 total enzyme units, $\mathrm{pH} 6.0$ for $18 \mathrm{~h}$ at $42^{\circ} \mathrm{C}$.
\end{abstract}

Keywords: Hydrolysis tissue, Epigyne, Bromelia antiacantha

\section{Introduction}

Methods for digesting soft tissues that surround sclerotized organs have been widely used in entomological studies in order to observe and identify small structures by scanning electron microscopy (SEM) or optical microscopy (Muff et al., 2007; Kim et al., 2007; Decae et al., 2007). Detailed morphological studies and identification of subtle differences, needed to resolve taxonomic problems and establish phylogenetic relationships between species (Marusik et al., 2009; Galiano, 2001; Platnick and Jäger, 2008), required the total removal of internal soft tissues for study by SEM (Griswold et al., 2005).

Conventional methods are available for elimination of soft tissues surrounding the entomological organs or structures like epigyne, a highly variable female reproductive structure in spiders (Ramírez 2000; Platnick et al., 1999). The most widely used treatments involve strong alkaline agents such as $\mathrm{NaOH}, \mathrm{KOH}$ as well as $\mathrm{NaClO}$. These strong chemical agents, however, tend to be aggressive and may damage the surface of the cuticle and a range of other chitinous structures, in essence precluding a comprehensive

\footnotetext{
* Correspondence: acantera@fq.edu.uy

${ }^{1}$ Laboratorio de Enzimas Hidrolíticas, Facultad de Ciencias, UdelaR, Montevideo, Uruguay

${ }^{2}$ Catedra de Bioquímica, Facultad de Química, UdelaR, Montevideo, Uruguay Full list of author information is available at the end of the article
}

morphological study (Álvarez-Padilla and Hormiga 2007; Sierwald, 1989).

A recent development for sample pre-treatment to remove soft tissue involves use of proteolytic enzymes. Enzymes are not chemically aggressive and allow for deep cleaning of a sample in which damage to organs under study can be avoided. The only reported use of proteolytic enzymes involved commercially available enzymes normally used for cleaning contact lens, i.e., trypsin and pancreatin (Álvarez-Padilla and Hormiga 2007; Dimitrov et al., 2007). This source of enzymes is expensive, and there are no standardized protocols developed for applications other than intended use. It is also important to consider enzyme stability as well as defining optimal parameters for use such as $\mathrm{pH}$ and temperature for hydrolysis of soft animal tissue.

The aim of this study was to evaluate digestion of soft tissue associated with epigyne using proteases present in vegetal extracts under controlled conditions of hydrolysis.

We describe a protocol for enzymatic cleaning of different entomological material in order to be able of being studied by SEM. We selected as enzymatic source proteases present in crude extract of $B$. antiacantha fruit. These enzymes have been studied and characterized for our group previously (Vallés et al., 2007). Based on optimal $\mathrm{pH}$ and temperature stability were combined 
different parameters in order to select the west conditions of soft tissue hydrolysis. In the present work are shown studies of specificity of these enzymes that strengthen the selection made.

\section{Material \& methods \\ Chemicals}

Bovine serum albumin (BSA), Coomassie Brilliant Blue R-250 (CBB), trichloroacetic acid (TCA), tri (hydroxymethyl) aminomethane (Tris), $\beta$-mercaptoethanol, casein, Insulin $\beta$ chain and Bradford reagent were obtained from Sigma-Aldrich (St. Louis, MO). Acrylamide, Azocasein, Trifluoroacetic acid (TFA) were obtained from Fluka (Milwaukee, WI)

All other chemicals used were of highest purity available from local commercial sources.

\section{Plants}

Ripe fruit from B. antiacantha was collected from plants grown in most soil with moderate lighting in the Departmento of Rocha (Uruguay) during early autumn 2011. Fruit was stored at $-20^{\circ} \mathrm{C}$. Plant fruit was deposited in a botanical collection in the Facultad de Química, UdelaR, Montevideo, Uruguay.

\section{Animals}

The epigyne used were from $A$. iheringi. Specimens were captured in pitfall traps in the suburb of Marindia (Canelones, Uruguay). The animals were subsequently stored in $70 \%$ ethanol at room temperature.

\section{Extraction of proteolytic enzymes}

Endocarp of B. antiacantha was first separated from the fruit skin and fiber. The endocarp tissue without seeds was then macerated using a mortar, without extracting medium, while maintaining the tissue and fruit juice cold using an ice bath. Endocarp crude extract (CE) was obtained by centrifugation at $6654 \times g$ (Sigma 3K18, Osterode am Harz, Germany) for $15 \mathrm{~min}$ at $4^{\circ} \mathrm{C}$ and clarification of the supernatant using Wathman filter paper No. 4. CE was fractionated and stored at $-20^{\circ} \mathrm{C}$. Protein content in CE was determined by the Bradford method (Bradford, 1976) using BSA as standard.

\section{Determination of proteolytic activity}

Proteolytic activity was determined using azocasein as substrate by a method modified from Andrew and Asenjo (Andrew BA and Asenjo JA, 1986). Briefly, CE was activated for $15 \mathrm{~min}$ at $4^{\circ} \mathrm{C}$ by addition of $\beta$ mercaptoethanol to $15 \mathrm{mM}$. Then, $340 \mu \mathrm{L}$ of a $1 / 200 \mathrm{di}-$ lution of activated CE, $340 \mu \mathrm{L}$ of $1 \%$ azocasein solution

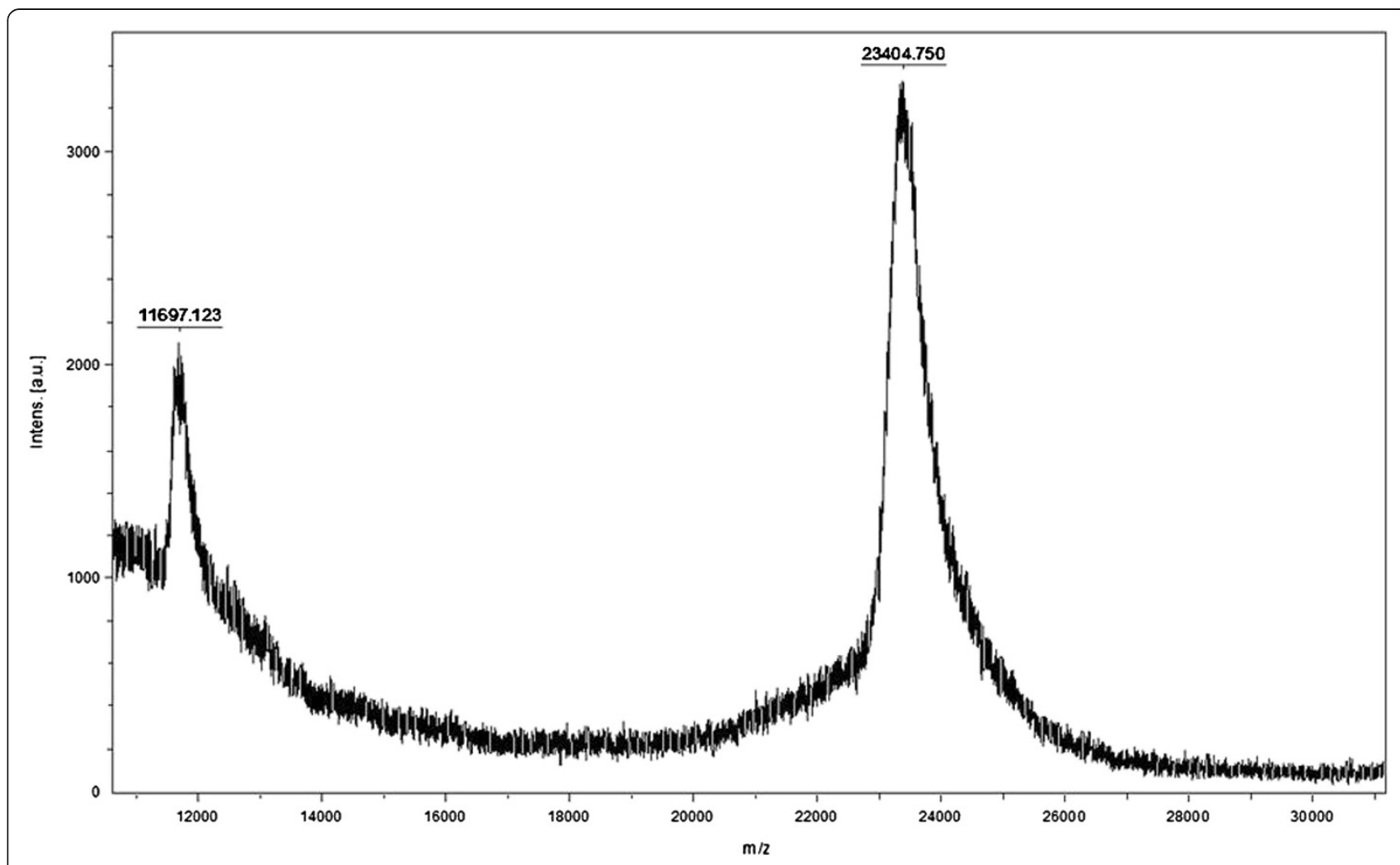

Figure 1 Mass spectrometry and determination of molecular weight of proteins present in CE of $B$. antiacantha by MALDI-TOF MS/MS. 


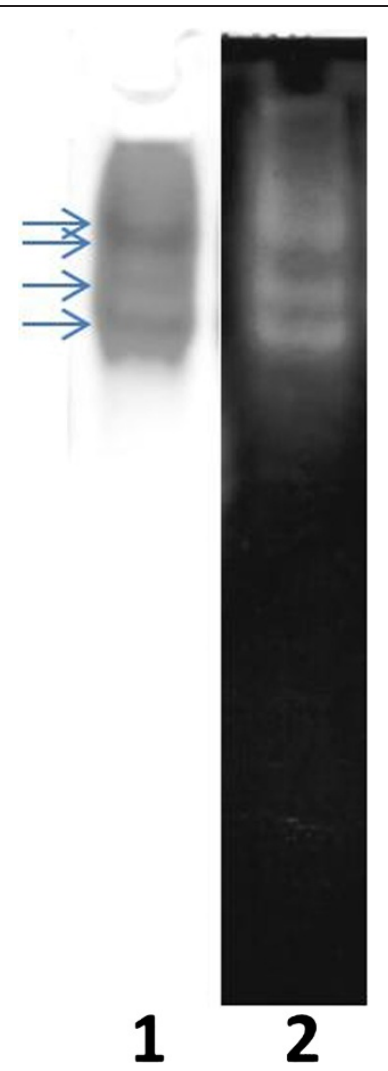

Figure 2 Native PAGE (lane 1) and Zymogram (lane 2); $25 \mu \mathrm{g}$ of protein of CE from B. antiacantha were loaded. The arrows represent the proteins bands with proteolytic activity.

(0.1 M Tris- $\mathrm{HCl}$ buffer, $\mathrm{pH}$ 7.2) and $340 \mu \mathrm{L}$ of $0.1 \mathrm{M}$ Tris- $\mathrm{HCl}, \mathrm{pH} 7.2$, were mixed and incubated $10 \mathrm{~min}$ at $37^{\circ} \mathrm{C}$. The reaction was stopped by addition of $340 \mu \mathrm{L}$ $10 \%$ TCA, centrifuged for $30 \mathrm{~min}$ at $13226 \times g$ and absorbance at $337 \mathrm{~nm}$ was measured. One enzyme unit $(E U)$ is defined as the amount of enzyme required to produce one unit increase in absorbance at $337 \mathrm{~nm}$ under conditions tested.

\section{Native PAGE and Zymogram}

$\mathrm{CE}$ was precipitated at $-20^{\circ} \mathrm{C}$ with addition of four volumes acetone and after centrifugation was suspended in
$0.1 \mathrm{M}$ Tris $-\mathrm{HCl}, \mathrm{pH}$ 8.8. $10 \mu \mathrm{L}$ aliquots were loaded onto $8 \times 10 \times 0.75 \mathrm{~cm} 10 \%$ polyacrylamide minigels. Two gels were run in parallel at $121 \mathrm{~V}$ for $1 \mathrm{~h}$. One gel was fixed and stained with CBB R-250, and the other was placed in contact with an agarose gel of the same dimensions that was. Transfer of proteolytic activity to the agarose gel was detected after drying and staining with $\mathrm{CBB}$ R-250 (Westergaar et al., 1980).

\section{Mass spectrometry}

A mixture of 1-2 $\mu \mathrm{L}$ crystallization solution (SA or HCCA) and $1 \mu \mathrm{L}$ of sample were prepared in a $200 \mu \mathrm{L}$ plastic tube. Volumes of between $0.5-1 \mu \mathrm{L}$ of this mixture were spotted on MTP 384 target plate polished steel (Bruker Daltonik $\mathrm{GmbH}$ ) and allowed to evaporate to dryness. Mass spectra were acquired on a Bruker Ultraflex (MALDI-TOF MS) spectrometer equipped with a pulsed nitrogen laser (337 $\mathrm{nm}$ ), in linear positive ion mode, using a $19 \mathrm{kV}$ acceleration voltage. Molecular mass of protein in CE was determined by MS using SA as matrix.

\section{Proteolytic enzyme specificity}

Hydrolysis reactions of reduced insulin $\beta$ chain were done in $50 \mathrm{mM}$ Tris- $\mathrm{HCl}, \mathrm{pH} 8.0,20 \mathrm{mM}$ cysteine and 0.0182: $9.1 \mathrm{nmol}$ enzyme- substrate ratio, at $37^{\circ} \mathrm{C}$. The reaction was stopped at $0,5,15,90 \mathrm{~min}$ and $16 \mathrm{~h}$ by adding $8 \mu \mathrm{L} 0.1 \%$ TFA $(\mathrm{v} / \mathrm{v})$ to $2 \mu \mathrm{L}$ of reaction mix. The reaction products at these times were crystallized with HCCA matrix in order to be analyzed by MALDI-TOF MS. Validation and positive control digestions were done using papain as reference enzyme, cysteine protease family C1A. The cleavage sites of the proteolytic enzymes in the insulin $\beta$ chain were determined using GPMAW software v6.0.

\section{Epigyne soft tissue digestion}

Epigyne structures were removed from animal specimens and stored in 70\% ethanol at room temperature prior to preparation. Samples were washed repeatedly with distilled water before treatment with enzymes. The epigyne, (ca. $10 \mathrm{mg}$ each) were incubated in $1.0 \mathrm{~mL}$ diluted enzyme solution at $\mathrm{pH} 4.0,6.0$ or 8.0 , and for

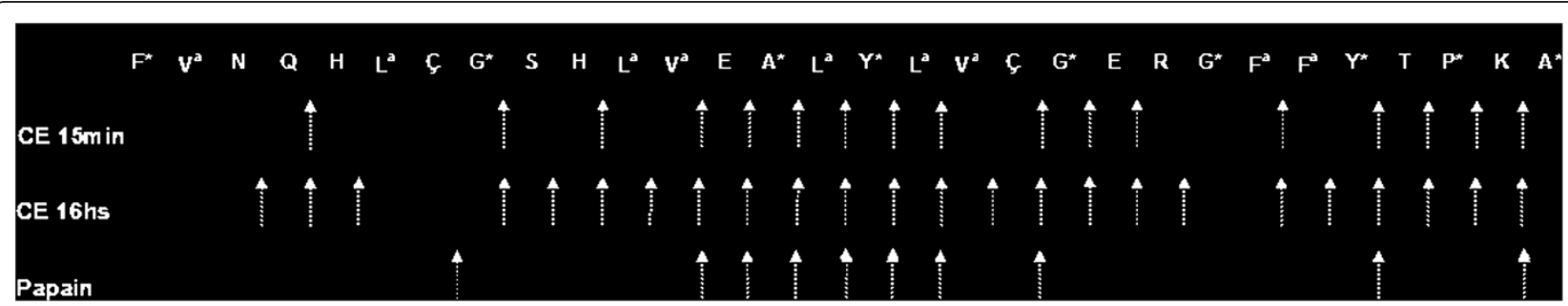

Figure 3 Determination of cleavage sites of papain and CE enzymes on insulin $\beta$ chain determined for fragments analysis by MALDITOF MS and GPMAW software v6.0. All insulin $\beta$ chain cleavage sites are shown with arrows, with positions indicating the $P^{\prime} 1$ cleavage site.

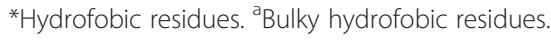


Table 1 Proteolysis conditions $(\mathrm{pH}$, incubation time, and specific activity $\mathrm{EU}_{\text {TOT }}$ ) evaluated for different samples

\begin{tabular}{lccc}
\hline Species & $\mathbf{p H}$ & Time (hs) & Enzyme unit (total)* \\
\hline & 4 & & 2,4 \\
& 6 & 22 & \\
A. iheringi & 8 & & 15,6 \\
& 6 & 6 & \\
& 8 & & \\
& 6 & 8 & \\
\hline
\end{tabular}

In all cases the treatment was done in a water bath at $42^{\circ} \mathrm{C}$ with continuous stirring. ${ }^{*} \mathrm{EU}_{\text {TOT }}$ means total activity at the volume of enzyme used in the treatment.

different times in a $42^{\circ} \mathrm{C}$ water bath with continuous stirring. The samples were washed and suspended in water, then sonicated (Sonicador ULTRONICS ${ }^{\mathrm{UL}} 16$, Teltow, Germany) for $15 \mathrm{~min}$. Subsequently, they were rinsed again and stored in $70 \%$ ethanol at room temperature until microscopically analysis. Negative controls included epigyne incubated without added enzyme in distilled water for $22 \mathrm{~h}$ at $42^{\circ} \mathrm{C}$ followed by sonication and storage. The enzymatic removal was evaluated by optical microscopy.

\section{SEM}

Samples were prepared for SEM (JOEL 9500, Tokoyo, Japan) using a standard protocol in which the samples were dehydrated in increasing concentrations of ethanol (50, 75 and 100\%), then mounted for examination after coating with gold/palladium alloy.

\section{Results}

CE obtained from fruit of $B$. antiacantha has 78.1 EU/ $\mathrm{mL}$ proteolytic activity, a protein concentration of 2.53 $\mathrm{mg} / \mathrm{mL}$, and thus a specific activity of $30.9 \mathrm{EU} / \mathrm{mL}$ proteins.

Molecular mass determination of the proteins present in the CE by mass spectrometry MALDI-TOF MS/MS shown a single peak of 23404 Da (Figure 1). When the proteins of CE were separated by Native Page, the electrophoresis showed at least 4 bands. All of these proteins bands had proteolytic activity revealed by the zymogram (Figure 2). These results suggest that the four proteases present in $\mathrm{CE}$ are isoforms with the same molecular weight.

Primary specificity of CE proteolytic enzymes was determined by hydrolysis of modified insulin $\beta$ chain (CBIc). Mass spectrometric analysis of the CBIc digestion fractions at $15 \mathrm{~min}$ resulted in the cleavage of more than 10 sites. The analysis of the CBIc digestion fractions for $16 \mathrm{~h}$ resulted in more than 20 cleavage sites (Figure 3). Digestion for $16 \mathrm{~h}$ with papain (used as positive control of the assay) showed 10 cleavage sites consistent with previous studies (Kaneda et al., 1995).

The proteolytic enzymes of Bromelia antiacantha were most frequently found to cleave the CBIc peptid bond adjacent to hydrophobic residues, a characteristic property for this cystein proteases family (Vallés et al., 2007). This broad specificity of CE proteases indicates excellent potential for enzymatic removal of diverse proteinaceous material from different sources.

Previous studies to determine the optimal temperature and $\mathrm{pH}$ for $\mathrm{CE}$ proteolytic enzymes showed highest activity at $60^{\circ} \mathrm{C}$ and between $\mathrm{pH}$ 6.0-9.0. The stability range for the activity was highest between $37-55^{\circ} \mathrm{C}$ and pH 4.0-9.0 (Vallés et al., 2007). Conditions selected for evaluation of optimizing digestion of epigyne soft tissues

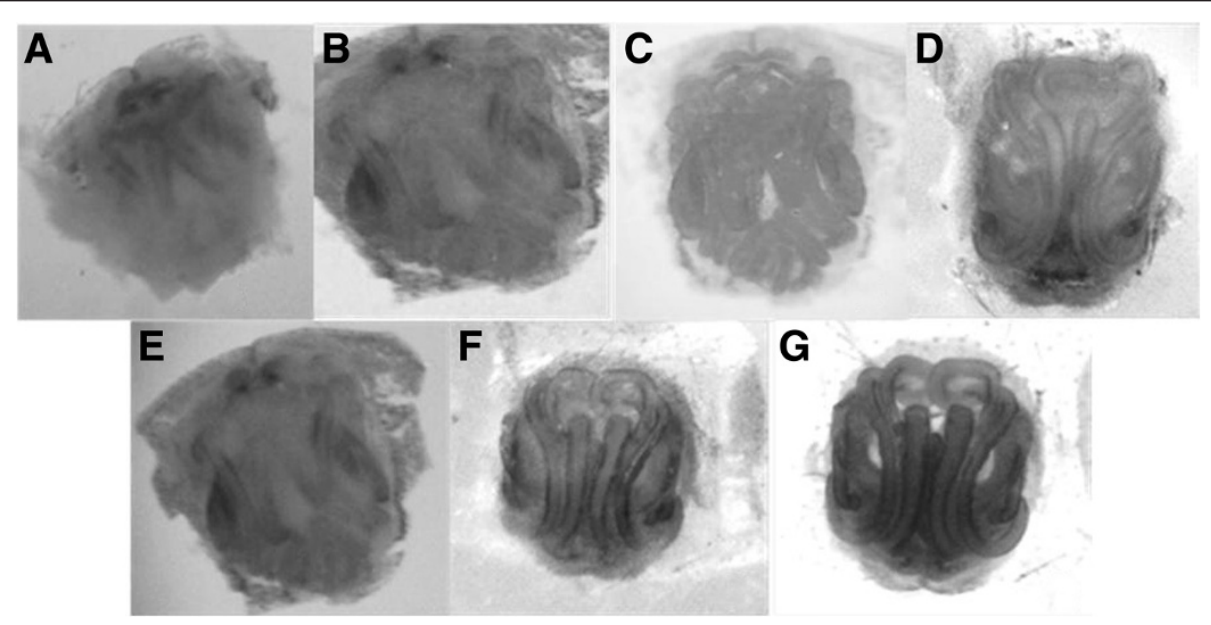

Figure 4 Photographs taken under increased ventral face of $A$. iheringi epigine subjected to various conditions of pH, $\mathrm{CE}$ specific activity and incubation time at $42^{\circ} \mathbf{C}$. Epigine treatment: $\mathbf{A}$ ) incubated in distilled water $\left.\left.22 \mathrm{~h}, \mathbf{B}\right) 2.4 \mathrm{EU}_{\text {TOT, }} \mathrm{pH} 4.0,22 \mathrm{~h}, \mathbf{C}\right) 2.4 \mathrm{EU}$ TOT, $0.1 \mathrm{M}$ Tris-HCl, pH 6.0, 22 h, D) $2.4 \mathrm{EU}_{\text {TOT, }} 0.1 \mathrm{M}$ Tris-HCl, pH 8.0, 22 h, E) $15.6 \mathrm{EU}_{\text {TOT }}, 0.1 \mathrm{M}$ Tris-HCl, pH 8.0, 6 h, F) 15.6 EU TOT, 0.1 M Tris- HCl, pH 6.0, $6 \mathrm{~h}$ and $\mathbf{G )} 15.6 \mathrm{EU}_{\text {TOT, }} 0.1 \mathrm{M}$ Tris-HCl, $\mathrm{pH}$ 6.0, $8 \mathrm{~h}$. 

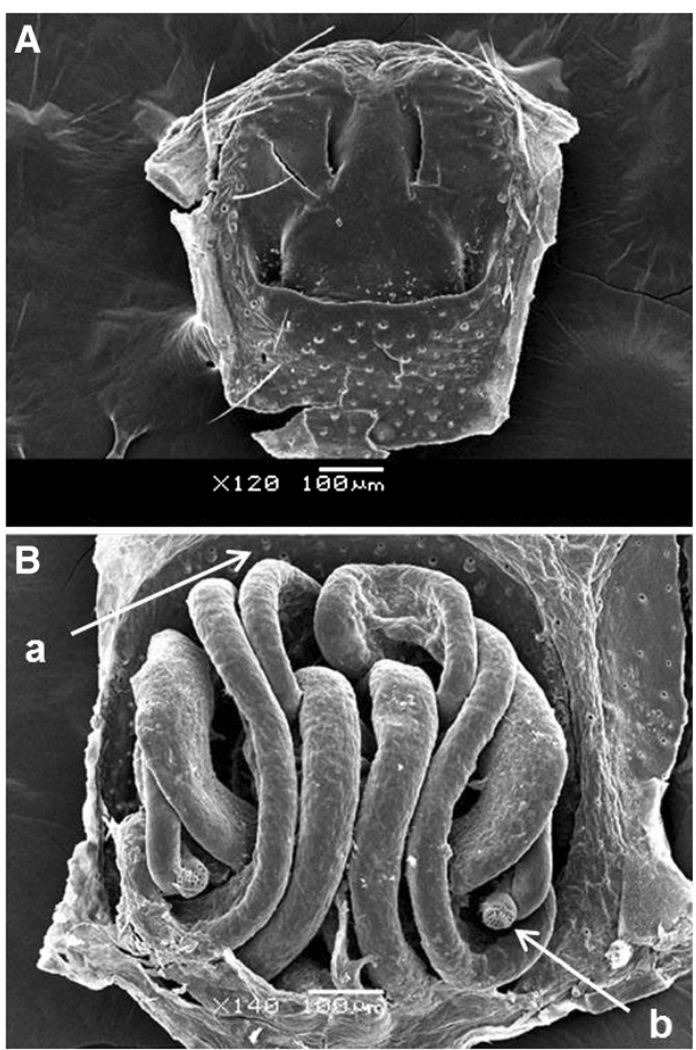

Figure 5 SEM image of $A$. iheringi epigyne treated for $8 \mathrm{~h}$ with 15.6 $\mathrm{EU}_{\text {TOт }}$ of $\mathrm{CE}\left(0.1 \mathrm{M}\right.$ Tris- $\mathrm{HCl}, \mathrm{pH} 6.0$ at $\left.42^{\circ} \mathrm{C}\right)$. Image A shows dorsal view and image $\mathbf{B}$ shows ventral view. In figure $\mathbf{B}$ can identified two structures: a) porous zone and b) spermathecae. were $\mathrm{pH} 4.0,6.0$ and 8.0 at $42^{\circ} \mathrm{C}$. Table 1 shows the conditions under which $\mathrm{CE}$ was tested in these initial experiments. The epigyne treated under these conditions were evaluated by optical microscopy (Figure 4).

Sonication of epigyne for $15 \mathrm{~min}$ without proteolytic enzyme treatment (Epigyne treated only by sonication during $15 \mathrm{~min}$,) did not result in removal of soft tissue (Figure 4a). The large amount of tissue present without added enzyme completely obstructed observation of underlying morphological structure. The soft tissues digestion was evaluated at the same amount of enzymes and different $\mathrm{pH}$. Treatment at $\mathrm{pH} 4.0$ resulted in virtually no removal of soft tissue (Figure 4b). There was also only a partial clearing of soft tissue with enzyme at $\mathrm{pH}$ 8.0 (Figure 4d). Adjustment of the $\mathrm{pH}$ to 6.0 with the same amount of enzyme resulted in complete digestion of soft tissue including the cleaning of ducts (Figure 4c). The high removal of soft tissues achieved at $\mathrm{pH} 6.0$ is also consistent with previously reported stability and optimum $\mathrm{pH}$ reported for these enzymes (Vallés et al., 2007). The large amounts of soft tissue remaining in epigyne enzymatically treated at $\mathrm{pH} \quad 4.0$ and 8.0 obstructed any detail in these structures when examined by optical microscopy made these samples unable to be studied by SEM.

Optimization of enzyme-substrate ratio and the time needed for effective cleaning were further evaluated at $\mathrm{pH} 6.0$ and 8.0. More effective digestion was achieved after $6 \mathrm{~h}$ at $\mathrm{pH} 6.0$ compared with the same treatment but at $\mathrm{pH} 8.0$ (Figure $4 \mathrm{e}$ and $\mathrm{f}$, respectively). There

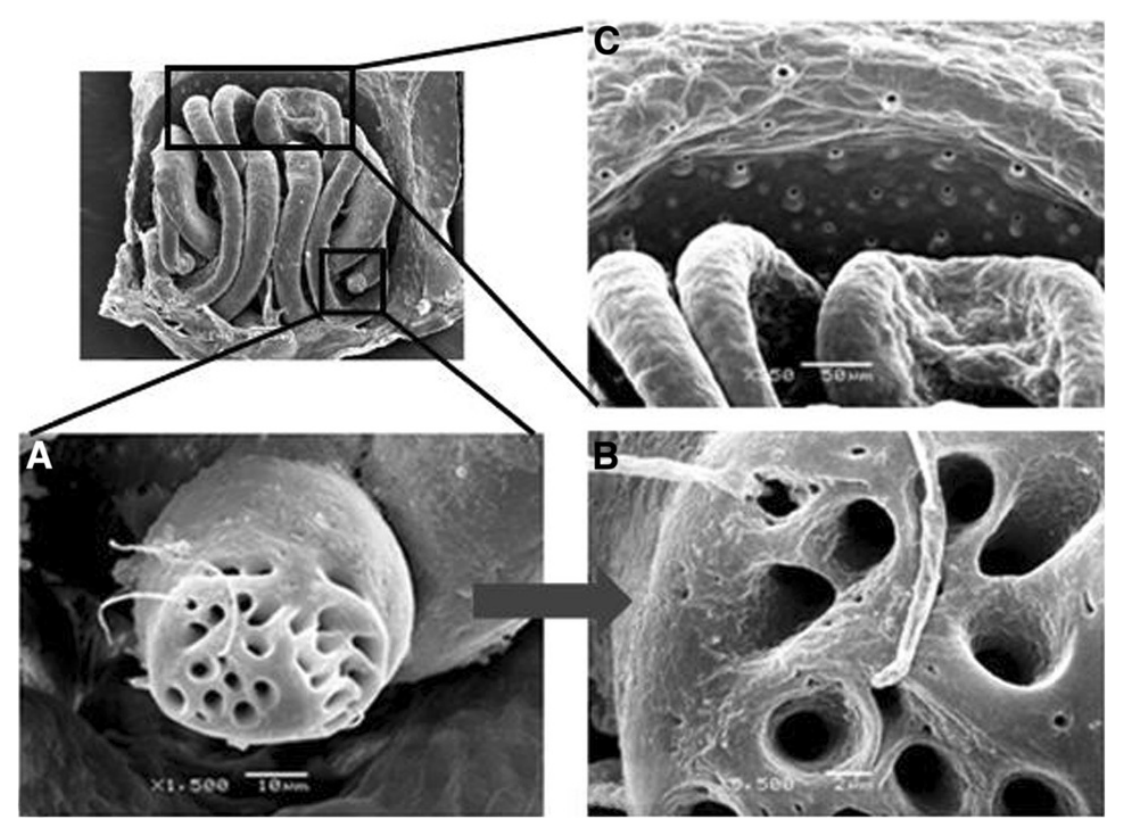

Figure 6 Spermatheca and porous zone shown at higher magnification: A) right spermathecae B) right spermatheca higher magnification and C) porous zone. 
was, in fact, virtually no difference between enzymetreated at $\mathrm{pH} 8.0$ and untreated epigyne (Figure $4 \mathrm{e} \mathrm{y} \mathrm{a,}$ respectively). Finally, treatment done at $\mathrm{pH} 6.0$ for $8 \mathrm{~h}$ resulted in complete removal of soft tissue from the epigyne structure (Figure 4g). These enzymatic cleaning conditions appeared to completely remove all soft tissue and were thus used for preparing epigyne for study by SEM.

Despite the great morphological complexity of the epigyne and number of ducts present, the complete removal of soft tissue is of great importance for taxonomic studies of these species (Figure 5). Structural detail of the epigyne in the absence of soft tissue was revealed including porous areas positioned behind the ducts and spermathecae (Figure 6). The spermathecae are internal female structures used for storing sperm after copulation and are very important for resolving systematic differences (Montes de Oca and Pérez-Miles 2009). In addition, some fibrous structures were evident that to our knowledge were not reported previously and are likely of non-protein composition (Figure 7). The cleaning treatment used enabled detailed observation of the chitinous cuticle surface of epigyne without observed damage, and thus providing an alternative to conventional chemical methods (Figures 6 and 7).

The time required for soft tissue removal using this enzymatic approach described here is much shorter than current conventional methods (Álvarez-Padilla and Hormiga 2007; Dimitrov et al., 2007). Furthermore, there was no observable damage to the chitinous cuticle of these structures like it was observed in samples treated with $\mathrm{KOH}$ which cuticle surface was digested by the caustic process making the specimen unsuitable for SEM (Álvarez-Padilla and Hormiga 2007). These results suggest the absence of chitinase enzymes in the CE.

The CE of $B$. antiacantha was also effective in removing epigyne soft tissue from two other spiders (Camillina chilensis and Anelosimus studiosus) using the same conditions as for A. iheringi (15.6 UE тот, $\mathrm{pH} 6.0$ for $8 \mathrm{~h}$ at $42^{\circ} \mathrm{C}$ ) (Data not shown). There is high variation in both the morphology and complexity of epigyne, and was the case for the three spiders used in this study. These species also likely have significant differences in protein composition of epigyne soft tissues. However, conditions for digestion of these soft tissues $(\mathrm{pH}$, temperature and enzyme activity) were the same. This may be due to the high efficiency in removal of proteinaceous material using the enzymatic extract of $B$. antiacantha. Significant differences in protein content and composition can be expected for other soft tissues in spiders and insects, and thus the method may be generally useful in entomology.
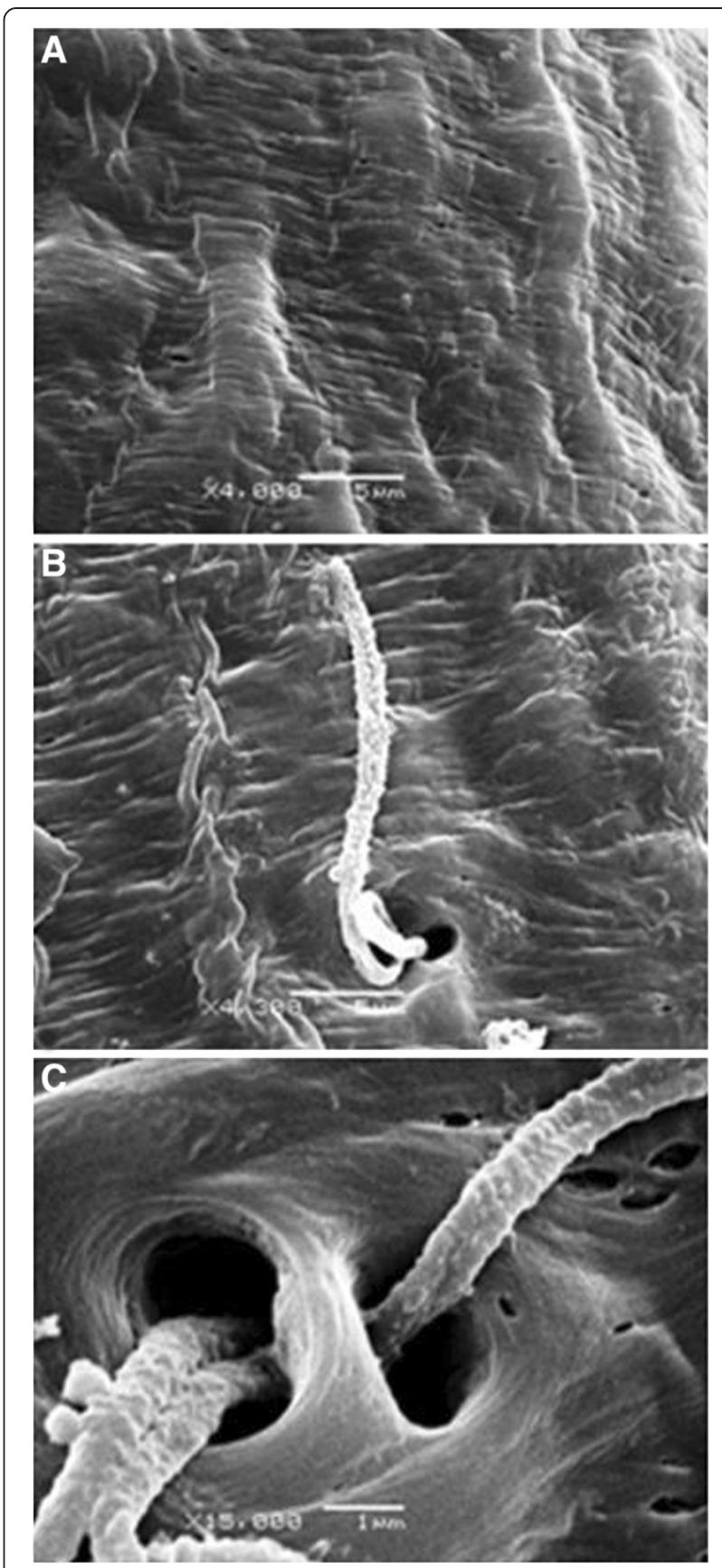

Figure 7 Surface duct and pore of epigyne shown at higher magnification: A) surface duct B and C) Pore of epigyne duct.

\section{Conclusions}

Crude extract from the ripe fruit of Bromelia antiacantha has four proteolytic enzymes isoforms with broad specificity.

These enzymes were very effective in total removal of soft tissue and cleaning of $A$. iheringi epigine for detailed structure analysis. Total elimination of soft tissues from epigyne was competed under optimized conditions (15.6 $\mathrm{UE}_{\text {тот, }} \mathrm{pH} 6.0$ for $8 \mathrm{~h}$ at $42^{\circ} \mathrm{C}$ ). 
Was described a novel, fast and economical protocol for cleaning entomological samples for use in SEM.

\section{Competing interests}

The authors declare that they have no competing interests.

\section{Authors' contributions}

LM performed all the research with de epigyne. DV performed all the research with the enzyme. AMC designed the research. LM, DV and AMC wrote the paper. All authors read and approved the final manuscript.

\section{Acknowledgments}

This work could't have been completed without Dr. Miguel Simo and Lic. Carolina Jorge (Facultad de Ciencias, Montevideo, Uruguay) scientific contribution.

\section{Author details}

'Laboratorio de Enzimas Hidrolíticas, Facultad de Ciencias, UdelaR, Montevideo, Uruquay. ${ }^{2}$ Catedra de Bioquímica, Facultad de Química, UdelaR, Montevideo, Uruguay. ${ }^{3}$ Current address: Iguá 4225, Montevideo 11400, Uruguay. ${ }^{4}$ Current address: General Flores 2124, Montevideo 11800, Uruguay.

Received: 21 March 2013 Accepted: 2 July 2013

Published: 9 July 2013

\section{References}

Álvarez-Padilla F, Hormiga G (2007) A protocol for digesting internal soft tissues and mounting spiders for scanning electron microscopy. J Arachnol 35:538-542

Andrew BA, Asenjo JA (1986) Synthesis and regulation of extracellular beta (1-3) glucanase and protease by cytophaga sp. In batch and continuous culture. Biotechnol Bioeng 28(9):1366-1375

Bradford MM (1976) A rapid and sensitive method for the quantitation of microgram quantities of protein utilizing the principle of protein-dye binding. Anal Biochem 72:248-254

Decae A, Cardoso P, Selden P (2007) Taxonomic Review of the Portuguese Nemesiidae (Araneae, Mygalomorphae). Revista Ibérica de Aracnología 14:1-18

Dimitrov D, Álvarez-Padilla F, Hormiga G (2007) The female genitalic morphology of the orb weaving spider genus Agriognatha (Araneae, Tetragnathidae). J Morphol 268:758-770

Galiano ME (2001) Revisión de las especies de Freya del grupo Decorata (Araneae, Salticidae). J Arachnol 29:21-41

Griswold CE, Ramírez MJ, Coddington JA, Platnick NI (2005) Atlas of phylogenetic data for entelegyne spiders (Araneae: Araneomorphae: Entelegynae) with comments on their phylogeny. Proceedings of the California Academy of Sciences, ser 4 56(suppl II):1-324

Kaneda M, Nagatome S, Uchikoba T (1995) Comparison of phytolacain R, a cysteine protease from Phytolacca americana, with papain. Phytochemistry 39:997-999

Kim BW, Lee W, Kwon TS (2007) A new species of the genus Ambanus (Arachnida: Araneae: Amaurobiidae) from Korea. Proc Biol Soc Wash 120:327-336

Marusik YM, Koponen S, Fritzén NR (2009) On two sibling Lathys species (Araneae, Dictynidae) from northern Europe. ZooKeys 16:181-196

Montes de Oca L, Pérez-Miles F (2009) Las arañas Mygalomorphae del Uruguay: clave para familias, géneros y especies. Revista del Laboratorio Tecnológico del Uruguay 4:41-49

Muff P, Schmidt MH, Frick H, Nentwig W, Kropf C (2007) Spider (Arachnida: Araneae) distribution across the timberline in the Swiss Central Alps (Alp Flix, Grisons) and three morphologically remarkable species. Arachnol Mitt 34:16-24

Platnick NI, Jäger P (2008) On the first Asian spiders of the family Caponiidae (Araneae, Haplogynae), with notes on the African genus Diploglena. Am Mus Novit 3634:1-12

Platnick NI, Grismado CJ, Ramírez MJ (1999) On the genera of the spider subfamily Otiothopinae (Araneae, Palpimanidae). Am Mus Novit 3257:1-25

Ramírez MJ (2000) Respiratory system morphology and the phylogeny of haplogyne spiders (Araneae, Araneomorphae). J Arachnol 28:149-157

Sierwald P (1989) Morphology and ontogeny of female copulatory organs in American Pisauridae, with pecial reference to homologous features (Arachnida: Araneae). Smithsonian Contributions to Zoology 484:1-24
Vallés D, Furtado S, Cantera AMB (2007) Characterization of news proteolytic enzymes from ripe fruits of Bromelia antiacantha Bertol. (Bromeliaceae). Enzyme Microb Technol 40:409-413

Westergaar JL, Hackbarth C, Treuhaft MW, Roberts RC (1980) Detection of proteinases in electrophoretograms of complex mixtures. J Immunol Meth 34:167-175

doi:10.1186/2193-1801-2-307

Cite this article as: Macció et al: Proteolytic enzymes from Bromelia antiacantha as tools for controlled tissue hydrolysis in entomology. SpringerPlus 2013 2:307.

\section{Submit your manuscript to a SpringerOpen ${ }^{\circ}$ journal and benefit from:}

- Convenient online submission

Rigorous peer review

- Immediate publication on acceptance

- Open access: articles freely available online

- High visibility within the field

- Retaining the copyright to your article

Submit your next manuscript at $>$ springeropen.com 